\title{
Kipling, Orwell, and the Humanities
}

\section{Glynn Custred}

In the 1990s I was active in a campaign in California to amend the state constitution to prohibit race, sex, and ethnic preferences in public employment, public contracting, and college admissions. The ballot initiative (California Proposition 209) attracted not only national, but also world-wide attention. One of the many newspapers that sent reporters to interview us was one in the San Francisco Bay Area. One afternoon the reporter and I sat in a sidewalk café where, in a relaxed conversational interview, I explained the rationale for the proposition. Everyone is different in some way or other, I said: different abilities, different upbringings, different educational levels, different creeds, national origin, social class, ethnic and racial affiliations-as indeed one would expect in a large, varied and dynamic society like ours. But those characteristics should never be the criteria for government mandated preferences conferred on one politically selected segment of the population to the disadvantage of the others. All citizens, regardless of their differences, must be treated equally before the law. As I argued my case, I recalled a poem I had read long ago which expressed part of my argument in verse.

East is East and West is West and never the twain will meet Till Earth and Sky stand present at God's great Judgement Seat

But there is neither East or West, border nor breed or birth When two strong men come face to face though they come from the ends of the Earth.

The article, when it appeared, accurately described my argument, but ended with, "then he quoted Kipling," implying that I had presented a clear argument for the ballot initiative, but that I had cast a shadow over it by

Glynn Custred is professor emeritus of anthropology at California State University, East Bay; glynncustred@sbcglobal.net. Professor Custred is the author of A History of Anthropology as a Holistic Science (2016) and last appeared in our pages in spring of 2021 with "From Bologna to Zoom: The Evolution of the University." 
quoting a poem by Rudyard Kipling. I never once thought of the author of that poem when I quoted those few lines of verse, just the appropriateness of what they had to say about the issue at hand. But I saw right away what the reporter meant, for despite his popularity in his own time, and his place in English literature (a bestselling author and in 1902 the first British recipient of the Nobel Prize for Literature) most people today, who have even heard more than just the name Rudyard Kipling, think of him only as an imperialist, a jingo nationalist, and a "racist."

I was reminded of that interview many years later when I read the introduction to an anthology of some of Kipling's short stories (Rudyard Kipling's Tales of Horror and Fantasy, 2008). The introduction was written by Neil Gaiman, himself an author of such stories. In the introduction Gaiman tells about an interview he once had with a journalist in which he had praised Kipling's stories. A short time later he received a letter from three of his fans asking how he, as a "trendy young man," could possibly regard Kipling as one of his favorite authors when Kipling was, as his fans informed him, “a fascist and a racist and a generally evil person."

Gaiman's response, in the introduction to the anthology, was that Kipling was many things that Gaiman was not, but that's what Gaiman said he likes in authors. In his opinion Kipling was "an astonishing writer, and arguably at his best in the short story form," an author who "wrote about real people, and his people feel very real" because Kipling had empathy with those about whom he was writing; "as much a poet of the dispossessed as he was a poet of Empire." And the best of his stories "are simply in the first rank of stories written in the English language."

The expression in verse of this empathy with real people, and their individual merit regardless of background, is what had stuck with me after all those years since first reading them, and why those lines spontaneously occurred to me in the interview when discussing diversity and individual merit in a contemporary political context. That indeed is the mark of an effective writer; someone who puts in words some observation or some sentiment that becomes part of one's repertoire of expressive resources.

Another poem in this regard is "Gunga Din" about a humble Indian servant during the time of British rule. The narrator is a British soldier, and the object of his respect is the regimental bhisti, or water bearer, Gunga Din. The narrator tells how shabbily Gunga Din was treated but also how faithfully he performed 
his duty under fire. When the narrator is wounded Gunga Din stops the bleeding, gives him water, and carries him to safety. During the retreat Gunga Din is wounded and once they reach cover he dies. The last stanza of the poem reads

Yes Din! Din! Din!

You lazarushian-leather Gunga Din

Though I've belted you an' flayed you,

By the livin' God that made you,

You're a better man than I am, Gunga Din.

(Lazarushian leather is military slang for dark-skinned). This empathy and recognition of individual merit, despite one's status and background, also held across class lines within the social hierarchy of Victorian England, where Kipling gave voice in some of his stories and poems to the lower classes and the subordinate. The poem "Tommy" speaks of the common soldier in the British army who was on the bottom of the social scale at the time, but who was essential for national and imperial security. (Thomas, or Tommy Atkins was a nickname given to privates in the army much like G. I. Joe in World War II. It was also used as a hypothetical name when instructing soldiers on how to fill out forms). Kipling describes this low status in the following way:

I went into a public 'house to get a pint of beer

The publican ‘e up an’ sez “we serve no redcoats here”...

We aren’t no thin red 'eroes, nor we aren’t no blackguards too,

But simple men in barricks, most remarkable like you.

And if sometime our conduck isn't all your fancy paints

Why single men in barricks don't grow into plaster saints ...

For it's Tommy this and Tommy that, an' "chuck him out the brute,"

But it's "savior of his country" when the guns begin to shoot.

None of that means that an Englishman in imperial service should sit on the club veranda in the afternoon sipping gin and tonic with a native servant, or that the common soldier-Tommy Atkins-should be invited into the officer's club for a pint of beer, for we are all different, all of us products of our social 
class and its different forms of upbringing, each class with its own way of life. But the value of those different stations to the common good should be recognized, and the virtue of individuals, regardless of status should not be taken for granted. In regard to empire Kipling, like many others of the time, focused on the civilizing mission of Western expansion, and Britain as its most exemplary agent. He expressed this in a poem written in 1898 shortly after the Spanish American War when the United States had entered that select group of Western countries by acquiring its own foreign possessions, along with bringing on all the trouble and responsibilities which came with them.

Take up the White Man's burden-

Send forth the best you breed-

Go bind your sons to exile

To serve your captive's need;

To wait in heavy harness,

On fluttered folk and wild-

Your new-caught sullen peoples,

Half Devil and half child ...

Take up the White Man's burden-

The savage wars of Peace-

Fill the mouth of Famine

And bid the sickness cease;

And when your goal is nearest

The end of others sought,

Watch sloth and heathen Folly

Bring all your hope to naught.

But the major import of these lines is to turn attention away from the pride and prestige of nation and empire to the sacrifices made by those on all levels of imperial service, as seen in the difficult tasks, performed in large part by the common man, of bringing the benefits of Western Civilization to the far ends of the earth, a view which completes the broader picture of late nineteenth century colonialism which is dominated today by the stereotype of the colonial master in pith helmet surrounded by servants, and by the nabobs who became rich in the process. "The savage wars of peace" often took place in regions of 
endemic tribal and petty state warfare where tranquility was essential for further progress in the march towards global modernity. And scientific advances during the nineteenth century had an increasing impact on medicine and on medical institutions from which the colonized countries benefited.

But Kipling's defense of imperialism was by no means unidimensional, for as a journalist traveling through the Raj and interacting with people of different kinds and on different social levels-both Indian and British-he saw different aspects of life within that varied population, some of which were not so flattering to the colonial masters, especially to some of the Englishmen who had drifted east in the wake of imperial expansion, two of whom are depicted in the story “The Man Who Would Be King.” These different aspects of British India and their stories are told by Kipling in his tales which range across the spectrum from adventure, fantasy, and horror to farce; stories that deal with the civil servants who administered British ruled India, and the military officers charged with maintaining the peace; by professionals such as engineers and physicians who worked under difficult conditions to improve the infrastructure and the health of the population; as well as those in the working class of British society who went out to India and to the other colonial possessions to make it all work, such as the army rank and file, railroad workers, and artisans of various kinds, all depicted as real people, who as Gaiman says, feel very real in the reading.

Kipling's endorsement of imperialism was not unqualified, for in "The White Man's Burden” he warns of the fragility of power. This warning is repeated in his poem "Recessional" along with a warning against the arrogance of those in authority, and what could happen to the British Empire if the British colonial administrators succumbed to those natural impulses. The poem appeared in the London Times in July of 1897 during the Jubilee which, at the height of British power and prestige, celebrated the fiftieth anniversary of the reign of Queen Victoria. The poem's didactic note and solemn tone, written in the form of a traditional English hymn, contrasted with the pomp and splendor of the occasion.

God of our fathers, known of old,

Lord of our far-flung battle-line,

Beneath whose awful Hand we hold

Dominion over palm and pine-

Lord God of Hosts, be with us yet, 
Lest we forget-lest we forget! . . .

Far-called, our navies melt away;

On dune and headland sinks the fire:

Lo, all our pomp of yesterday

Is one with Nineveh and Tyre!

Judge of the Nations, spare us yet,

Lest we forget-lest we forget!

If, drunk with sight of power, we loose

Wild tongues that have not Thee in awe,

Such boastings as the Gentiles use,

Or lesser breeds without the Law-

Lord God of Hosts, be with us yet,

Lest we forget-lest we forget!

Here, as in “The White Man's Burden,” the varied native peoples of the empire are seen as culturally inferior to those of the colonial powers, to those who profited from the conquered lands, but those who also, with some sacrifice, strove to bring to those peoples security and the benefits of modern civilization. This view of the natives is indeed an ethnocentric stereotype, as much as is the opposing Western stereotype of the Noble Savage, noble precisely because they are not Western-two sides of the same stereotypical coin. This expression of Western superiority and nationalism has long been roundly criticized, for Kipling was out of the liberal mainstream of his time, especially that of the anti-imperialist “Little England” movement within the Liberal Party. This criticism increased with the disillusionment that set in after World War I and the decreasing enthusiasm for empire as the century wore on. Yet while condemning him for his political stance, those critics also recognized, to one degree or another, the quality of his work. This is seen in the essays of such authors and critics as W. H. Auden, Edmund Wilson, William Butler Yeats, Henry James, T. S. Eliot, and Irving Howe.

One of the most interesting and harshest of those critics is George Orwell, as seen in his essay on Kipling written in 1942. Orwell writes that "every enlightened person has despised him"; that Kipling is "morally insensitive and aesthetically disgusting” and that “it is no use pretending that Kipling's view of 
life, as a whole, can be accepted or forgiven by civilized persons," for "Kipling himself was only half civilized." Orwell also said that the late nineteenth century Anglo-Indians were the least sympathetic to him. Reading this reminded me of an elderly Englishman I once met in a boarding house in Lima, Peru where I stayed for a short time in 1963 before beginning my field work in the Andean highlands. He must have been in his late eighties or early nineties. When I asked him what part of England he was from, he said that he was from India. When I said "Oh, like Rudyard Kipling," he let me know in no uncertain terms that he and the other Anglo-Indians thought very little of Kipling. In that regard Orwell writes that Kipling's literary representation of Anglo-Indians is "tawdry and shallow," but that his "is the only literary picture that we possess of the nineteenth century Anglo-Indian," and that Kipling "could only make it because he was just coarse enough to be able to exist and keep his mouth shut in clubs and regimental messes." Another way of looking at it is that Kipling's view of Anglo-Indians was honest, seeing the benefits of their work and yet describing the people and their way of life as they really were.

Orwell was in a particularly good position to assess Kipling’s view of colonialism, for he, like Kipling was born in India when that country was the Jewel in the Crown of the British Empire. Kipling was born in Bombay (Mumbai) in 1865 and Orwell (the pen name of Eric Blair) thirty-eight years later (1903) in Motihari in the eastern part of the country. Kipling's father was a professor and the principal of an art school in Bombay, and Orwell's maternal grandfather was a teak merchant in Burma, where Orwell's mother was born. Kipling spent the first six years of his life in India with a native nurse where he learned the local language. Orwell's mother took him to England when he was only two, but both families, the Kiplings and the Blairs, when in England remained in contact with other Anglo-Indians.

Kipling went to what has been described as a second-rate boarding school for impoverished army officers, an experience which was the source of his collection of short stories titled Stalky and Co. Orwell attended fashionable private schools and later Eton which was the source of his story "Such, Such Were the Joys," published posthumously in the Partisan Review in 1957, a humorous although exaggerated account of his days there that did the school's reputation no good. Both men were meant for imperial service. Kipling’s bad eyesight prevented him from following that career path, so he returned to India as a 
journalist. Orwell, after Eton, joined the Imperial Police and served in Burma where he learned the local language.

Their literary careers partly overlapped, for Orwell was thirty-three and an author when Kipling died in 1936. Yet despite those similarities, their views of empire radically diverged, with Kipling becoming what has been called the interpreter of imperial Britain, and Orwell a staunch opponent of imperialism. This was clearly demonstrated in his essay “On Shooting an Elephant," in which the local authority is goaded to an unnecessary act by a native crowd in order to save face, in the essay “A Hanging," and later in his novel Burmese Days, all based on his experience in imperial service in Burma. Orwell eventually resigned, later writing that he was unsuited for that line of work. One thing Orwell and Kipling did have in common was an empathy for the common man. Kipling had direct experience with people of different social classes and occupations which were the topics of his stories and poems, mainly through his work as a journalist, but also during his time in London where he frequented the music halls and learned to appreciate the popular culture of the common people, and where he found some of the inspiration for his poetry.

Orwell too interacted with common people in a conscious attempt to experience first-hand their way of life. He describes this in his explanation for leaving the imperial police, "I felt I had to escape not merely from imperialism but from every form of man's dominion over man. I wanted to submerge myself, to be one of the oppressed, to be of them and on their side against the tyrants." After leaving imperial service he spent some time traveling, living for a while a vagabond life which he describes in Down and out in Paris and London, living with a working-class family, and working at menial jobs to get to know, first hand, the kind of people whom leftist intellectuals championed, but with whom very few had any direct contact. He describes that experience in Road to Wigan Pier, a non-fiction description which includes the hardship and dangers of coal miners whose work was important for the functioning of the industrial society of the time.

Where his and Kipling's interest merged was sympathy for the common soldier as expressed by Kipling in “Tommy Atkins”:

Making mock of uniforms that guard you while you sleep,

Is cheaper than them uniforms and they're starvation cheap. 
Orwell says that Kipling's "grasp of the function of who protects whom, is very sound" for he "sees clearly that man can only be highly civilized while other men inevitably less civilized are there to guard and feed him," an opinion later described, but wrongly attributed to Orwell, as "people sleep peacefully in their beds at night because rough men stand ready to do violence in their behalf."

Both men also experienced disillusion at what their worlds had become; Kipling with the First World War, and Orwell with his experience in the Spanish Civil War. Kipling had seen the war coming and had warned that his beloved British army was unprepared for the conflict. His views were regarded as reactionary by the Liberal Party which was in power at the time. Kipling also loathed the Germans, a sentiment he expressed in poems and in the short story "Mary Postgate." When the war began, his only son was sixteen, going on seventeen and enrolled in a school that would prepare him for a later military career. Like his father, the son had poor eye sight and Kipling had to pull strings to get him a commission in an Irish regiment. In 1915 his son was reported missing in action, and after interviews with his comrades-in-arms and later investigation Kipling determined that he had been killed in action. He wrote a poem, "My Son Jack," expressing his despair at the loss. He was also asked to write a history of the Irish Guards, the unit in which his son had served, which he did, and which is considered exemplary for the genre.

When the Spanish Civil War broke out in 1936 it became clear that the two factions in the conflict were supported by outside forces; the Soviet Communists were on the Republican side, and the Italian Fascists and German Nazis were on the side of dictator Francisco Franco. Orwell joined and fought in a Spanish militia called the POUM, the Worker's Party of Marxist Unification whose members had been inspired by the writings of Leon Trotsky. Orwell was wounded in combat and later saw his comrades and others persecuted in the thousands by the Stalinists who were purging the movement of any internal competition. Orwell was lucky to escape; he describes these experiences in Homage to Catalonia. He remained committed to socialism but was a vociferous opponent of totalitarianism regardless of its ideological rationalization. We see this in an essay titled "Politics and the English Language" in which he shows how language is perverted for ideological purposes, as well as in his allegoric novella Animal Farm and his dystopic novel 1984 in which he projects onto an imagined future what was then happening in Stalinist Russia. 
We see in Kipling and Orwell two Englishmen born in India during the heyday of empire who shared a common interest in and concern for the common man, sentiments which were based on their own personal experiences. They were diametrically opposed in other respects, however. Empire was backed by Kipling but with warnings of what could happen if arrogance replaced pride, while Orwell condemned all colonial regimes as oppressive. Kipling emphasized the sacrifice of those in colonial service, while Orwell sympathized with those who had been subjugated in the process both domestically and abroad. Both wanted to advance the benefits of modernity, but while Kipling saw this in terms of the civilizing mission of the West by means of colonialization, even in the face of its costs, Orwell saw it through the lens of faith in a utopian ideology which turned out to be a god that failed. And both of these antithetical visions were clearly expressed in the literary production of two important writers whose careers converged in the first decades of the twentieth century.

The study of Kipling and Orwell demonstrates how much is to be gained from a proper education in the humanities. It is through the humanities that we learn how to evaluate art, music, and literature by exploring how others have perceived and experienced life. The humanities also teach us how to evaluate those works, thus sharpening our critical skills while stimulating the imagination. Such critical evaluations will always vary, sometimes sharply, as we see in the different world views and in the writings of Kipling and Orwell, and how they have been analyzed and debated over time. Rational debate thus forms a part of the educational process, especially in the university.

Today, however, rather than encouraging rational debate, university courses in literature have become instruments of indoctrination, purging the canon of the best works of literature, and replacing them with writers who adhere to a single, narrowly focused party line, squelching the imagination and leaving students incapable of thoughtful evaluation, all in the interest of ideological conformity. In every way this is a betrayal of the humanities and of the purpose of a liberal education. 